\title{
Epoxy Nanocomposites with Increased Hydroabrasive Wear Resistance for Use in Vehicles
}

\author{
A.V. Buketov*, V.M. Husiev, A.G. Kulinich, S.V. Yakushchenko, S.O. Smetankin, \\ V.V. Sotsenko, K.Yu. Yurenin
}

\author{
Kherson State Maritime Academy, 20, Ushakov Ave., 73003 Kherson, Ukraine
}

(Received 16 April 2021; revised manuscript received 20 October 2021; published online 25 October 2021)

\begin{abstract}
Reinforced and filled polymeric composite materials (CMs) are gaining the interest of scientists, researchers and industrialists all over the world. Polymeric composites being lighter and cheaper than the metal-based composites are seen as a scope for advancement in the ever-evolving field of materials science. Moreover, polymeric CMs have widely spread in different branches of industry, especially water transport. Therefore, it was substantiated in the work that an important operational property of vehicles, which determines their durability and service life, is wear resistance (determined by wear intensity) under the action of hydroabrasive. In this regard, the use of polymeric composites, including epoxy and protective coatings, based on them, is relevant for the part restoration. It has been shown that the developed CM has high potential for improving vehicle parts. The epoxy composite matrix modified by 4 -aminobenzoic acid was prepared with loading of active dispersed particles in the form of a synthesized titanium-aluminum powder mixture $\left(\mathrm{Ti}(70 \%)+\mathrm{Al}_{3} \mathrm{Ti}(15 \%)+\mathrm{Ti}_{3} \mathrm{AlC}_{2}(15 \%)\right)$, powder mixture $\left(\mathrm{TiH}_{2}(65 \%), \mathrm{FeSiMn}(30 \%)\right.$, $\mathrm{B}_{4} \mathrm{C}(5 \%)$ ), and discrete carbon fibers FC-H. The optimum content of the fillers has been found (pts. wt.): $0.4-0.6: 0.04-0.06: 55-65$. The CM is characterized by lower wear intensity under the conditions of hydroabrasive, compared to known world analogues. This indicates the feasibility of using the developed material to increase hydroabrasive wear resistance of water transport parts, which operate under the action of mechanical loads and elevated temperatures. The broad applicability of the developed material as a functional protective coating has been confirmed. The application of the developed protective coating to the transport allows to reduce the wear intensity from the action of hydroabrasive parts by 2.4-3.6 times, and the rate of restoring defective parts by 2.0-2.5 times.
\end{abstract}

Keywords: Nanocomposite material, Wear intensity, Hydroabrasive, Transport.

\section{INTRODUCTION}

It is known [1-7] that strength, hardness, elasticity, heat resistance, etc. are important characteristics of vehicle parts. At the same time, low indicators of mechanical and thermophysical properties of metals and alloys, which are the basis for the formation of parts and units of vehicles, during operation lead to fatigue of materials [8-12]. The latter, in turn, is the cause of premature aging of metals and alloys, which significantly reduces the service life of equipment.

The authors of $[5,13-15]$ show that wear resistance (determined by the intensity of operation) under the conditions of hydroabrasive is an important performance property of vehicles, which determines their durability and service life. In this regard, the use of polymeric composites, including epoxy and protective coatings based on them, is relevant for the restoration of units. To improve the cohesive properties of materials and their wear resistance, the modifiers, plasticizers and fillers of different physical nature are introduced into polymer composite materials $(\mathrm{CMs})$ in an optimal amount $[16,17]$. This allows to increase the service life of vehicle equipment due to the increased performance of mechanical properties and wear resistance of polymer composites.

The aim of the work is to develop polymer composites and protective coatings based on them with increased hydroabrasive wear resistance for vehicles.

\section{MATERIALS AND METHODS}

An epoxy diane oligomer ED-20 (ISO 18280:2010) was chosen as the main component of the binder in the formation of composites. Low molecular weight oligomer has significant indicators of adhesive properties, destructive stresses in bending, impact strength and other physical and mechanical properties, slight shrinkage during polymerization.

Polyethylene polyamine (PEPA) (TU 6-05-241-20278) was used for polymerization of the compositions.

4-Aminobenzoic acid was used as a modifier. The modifier was introduced into the binder with a content of 0.1 to $2.0 \mathrm{wt}$ \% per $100 \mathrm{wt}$ \% of the epoxy oligomer ED-20 (hereinafter modifier quantity in wt. \% referred to 100 wt. \% of epoxy oligomer ED-20). 4-Aminobenzoic acid has the following properties: molecular formula $\mathrm{C}_{7} \mathrm{H}_{7} \mathrm{NO}_{2}$, molar mass $137.14 \mathrm{~g} / \mathrm{mol}$, density $1.374 \mathrm{~g} / \mathrm{cm}^{3}$.

Synthesized powdery titanium-aluminum mixture (SPTAM) was used as a microdisperse filler in the experiment. The filler was formed by high-voltage electric discharge (HVED) synthesis. The filler has the following composition: $\mathrm{Ti}(70 \%)+\mathrm{Al}_{3} \mathrm{Ti}(15 \%)+\mathrm{Ti}_{3} \mathrm{AlC}_{2}$ (15\%) $(d=15-18 \mathrm{~nm})$.

Additionally, a microdisperse powdery mixture (MPM) was used to improve the properties of the polymeric CM. The MPM has the following composition: $\mathrm{TiH}_{2}(65 \%)$, FeSiMn $(30 \%), \mathrm{B}_{4} \mathrm{C}(5 \%)(d=63 \mu \mathrm{m})$.

FC-H carbon discrete fibers $(\mathrm{CDFs})(d=9-11 \mu \mathrm{m}$, $l=20-30 \mu \mathrm{m})$ also were used in the formation of wear-

\footnotetext{
*buketov.andrey@gmail.com
} 
resistant CM. Carbon fibers are characterized by high tensile strength, low specific gravity, low coefficient of thermal expansion, and chemical inertness. Carbon fiber, due to its structure, is characterized by a developed surface that provides the necessary sorption characteristics. Characteristics of FC-H carbon fibers are the following: density $200 \pm 10 \mathrm{~g} / \mathrm{m}^{3}$, active carbon content $>50 \mathrm{~g} / \mathrm{m}^{2}$, adsorption of carbon tetrachloride $37 \%$, adsorption of benzene $27.3 \%$, adsorption of iodine $>1000 \mathrm{mg} / \mathrm{g}$.

The relative resistance of $\mathrm{CMs}$ to the action of hydroabrasive was determined by a technique that allows to model real processes of wear of parts of mechanisms under the action of hydroabrasive. The rotation speed of the rotor of the centrifugal accelerator was $3000 \mathrm{rpm}$. A mixture of technical water and abrasive particles of quartz sand (5:1 by volume) was used as a hydroabrasive suspension. Samples with a size of $30 \times 20 \times 4 \mathrm{~mm}$ were studied by changing the angle of attack of the hydroabrasive mixture, which was $\alpha=45^{\circ}$ (see Fig. 1). The mass of quartz sand used in the study was $m=9 \pm 0.1 \mathrm{~kg}$.

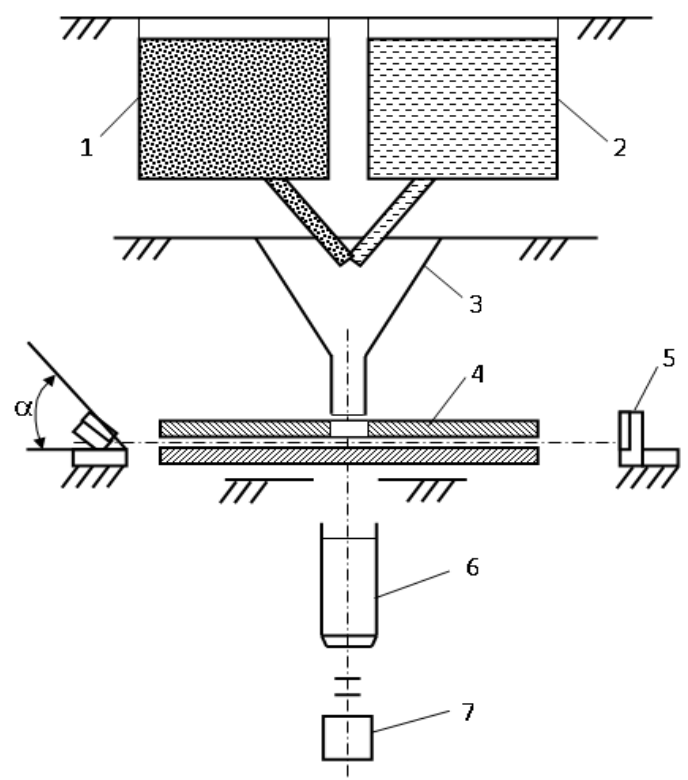

Fig. 1 - The scheme of the centrifugal accelerator: 1 - container with abrasive particles; 2 - container with technical water; 3 - hopper for mixing abrasive particles with water; 4 - rotor; 5 - sample with coating; 6 - electric motor; 7 - tachometer

The relative wear intensity was determined by the formula:

$$
I=\frac{m_{0}-m_{\kappa}}{m_{0}} \cdot 100 \%,
$$

where $m_{0}$ is the mass of the sample at the beginning of the study, $\mathrm{kg} ; m_{k}$ is the mass of the sample at the end of the study, $\mathrm{kg}$.

Weighing of samples before and after tests was performed on electronic scales DRS-8000 "SHIMADZU" with an accuracy of $0.02 \pm 0.001 \mathrm{~g}$.

\section{RESULTS AND DISCUSSION}

Taking into account the results of previous studies [18-21], we tested and established indicators of wear intensity under the influence of hydroabrasive of the following materials:

- matrix (control sample);

- CM 1 (the composite was formed in the following ratio - binder : modifier 4-aminobenzoic acid : SPTAM, with the following composition ( $\mathrm{Ti}(70 \%)+\mathrm{Al}_{3} \mathrm{Ti}(15 \%)$ $\left.+\mathrm{Ti}_{3} \mathrm{AlC}_{2}(15 \%)\right)$ : carbon fiber $\mathrm{FC}-\mathrm{H}$ : powder mixture, with the following composition $\left(\mathrm{TiH}_{2}(65 \%)\right.$, FeSiMn (30\%), $\left.\left.\mathrm{B}_{4} \mathrm{C}(5 \%)\right)-100: 0.1: 0.5: 0.05: 60\right)$;

1) $\mathrm{CM} 2$ (the composite was formed in the following ratio - binder : modifier 4-aminobenzoic acid : SPTAM : carbon fiber FC-H : powder mixture - $100: 0.1: 0.3$ : $0.05: 40$ );

2) CM 3 - Jotacote Universal N10 QD composite (Jotun, Norway);

3) CM 4 - Intershield 300 composite (International, Great Britain)

Note that the study of the intensity of operation under the influence of hydroabrasive polymer composites was performed on a centrifugal accelerator at an angle of attack of the hydroabrasive mixture $a=45^{\circ}$. This angle is chosen on the condition that the tangential and normal stresses that occur on the surface of the samples are maximum. And this, in turn, leads to the maximum destruction of materials, which well illustrates the behavior of composites under the influence of critical loads during the operation of equipment.

In addition, we note that at the initial stage we developed a modified epoxy matrix with improved mechanical properties.

The development is based on the task of increasing the indicators of adhesive strength, physical and mechanical and thermophysical properties of the matrix for the formation of composites that operate under the influence of hydroabrasive. The matrix was formed by creating a modified epoxy binder with improved properties, containing epoxy diane resin, a modifier and a hardener; and as a modifier it contains 4 -aminobenzoic acid with the following ratio, wt. \%:

$$
\begin{array}{ll}
\text { - epoxy diane resin } & 100 \\
\text { - hardener } & 10-12 \\
\text { - modifier 4-aminobenzoic acid } & 0.1-0.3
\end{array}
$$

It was experimentally found (Fig. 2) that the sample based on the original epoxy matrix, under the same test conditions showed maximum intensity of hydroabrasive wear $(I=43 \%)$. This is primarily due to the low cohesion strength of such a material, which additionally contains, compared to other studied composites, a significant percentage of the sol fraction. The latter, although it provides the damping properties of the matrix, causes the appearance of air inclusions in the material. This not only reduces the cohesive properties, but also affects the intensity of wear of the epoxy matrix.

It has been proved (Fig. 2) that the developed material CM 1 had the lowest wear intensity $(I=10 \%)$ among the whole spectrum of investigated materials. The optimum content of dispersed fillers and carbon fibers was established on the basis of preliminary studies and mathematical planning of the experiment. It can be argued that the modifier, dispersed particles, 
and CDFs are active to the interfacial interaction with macromolecules of the epoxy oligomer during crosslinking of composites, which leads to the formation of a material with a strongly crosslinked structure. It was assumed that the active centers of the modifier and fillers are involved in crosslinking with hydroxyl, epoxy, carbonyl, and carboxyl groups of the epoxy oligomer. In turn, this provides an increase in the content of the gel fraction in the CM, which provides an increase in its cohesive strength. As a result, the wear intensity of such a material is significantly reduced, and, consequently, its hydroabrasive wear resistance increases.

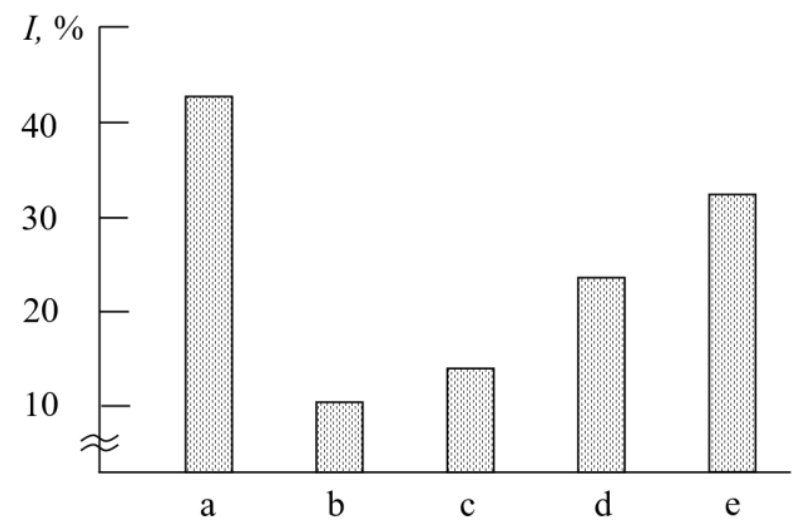

Fig. 2 - Dependence of the wear intensity $(I, \%)$ at the particle angle of attack $\alpha=45^{\circ}$ on the content and nature of ingredients in composites: a) matrix (control sample); b) CM 1; c) CM 2; d) CM 3; e) CM 4

Slightly higher values of the wear intensity were observed for samples based on CM 2. For such a material, the wear intensity under the influence of hydroabrasive was $I=14 \%$. In our opinion, this is due to insufficient wetting of the fillers and CDFs with the epoxy oligomer, despite the preliminary ultrasonic treatment of epoxy compositions. Therefore, the number of physical and chemical bonds at the phase boundary per unit volume of the composite are decreased, which leads to deterioration of the intensity of CM 2 compared to CM 1.

The wear intensity of known and widely used materials on epoxy basis (CM 3 and CM 4), which are used to protect vehicles, was studied for comparison under similar conditions. It was shown (Fig. 2) that for such materials (CM 3, CM 4) the following characteristics of the wear intensity were obtained under conditions of hydroabrasive action: $I=24 \%, I=36 \%$, respectively.

It can be stated that the material (CM 1), on the basis of a modified epoxy matrix filled with active dispersed particles and CDFs at the optimal content, was developed in the work. The developed material has 2.43.6 times better wear intensity under the conditions of hydroabrasive compared to well-known analogues. This is evidence of the need to use the developed material and a coating based on it to increase the hydroabrasive wear resistance of water transport parts that operate under the influence of mechanical loads and elevated temperatures.

\subsection{Epoxy Nanocomposite Coating with Increased Resistance to Hydroabrasive Based on Modified Epoxy Binder (ENCC)}

The main purpose is to increase the indicators of hydroabrasive wear resistance and physical and mechanical properties of technological equipment, which operates under the influence of aggressive environments.

The technology of forming an epoxy composite is the following: i) heating the epoxy resin to a temperature $T=353 \pm 2 \mathrm{~K}$; ii) exposure in the chamber for a time $\tau=20 \pm 0.1 \mathrm{~min}$; iii) mixing the binder with the modifier and microdisperse filler for $\tau=10 \pm 0.1 \mathrm{~min}$; iv) ultrasonic treatment of the composition for a time $\tau=1.5 \pm 0.1 \mathrm{~min}$; v) cooling the mixture to room temperature $(\tau=60 \pm 5 \mathrm{~min})$; vi) introducing the hardener and mixing the composition for $\tau=5 \pm 0.1 \mathrm{~min}$.

Temperature-time regime of the heat treatment process is shown in Fig. 3. The application of the developed protective coating on ship structures is performed by the method of pneumatic spraying of adhesive with a thickness of 0.1-0.3 mm, which can significantly increase the adhesive strength, physical and mechanical properties and hydroabrasive wear resistance of the protective coating.

It should be noted that the quality of the protective surface preparation largely determines the reliability and durability of the protective coating. Surface preparation consists in degreasing and removing various contaminants, scale, rust by sandblasting.



Fig. 3 -Scheme of the temperature-time regime of the polymer composites formation

Then, the fillers are added to the epoxy resin in appropriate proportions and hydrodynamically combined. After hydrodynamic mixing of the components, the 
hardener is introduced immediately before applying the composition to the part surface.

ENCC coating contains the following components (see Table 1).

The obtained results of tests of adhesive strength, physical and mechanical and thermophysical properties and hydroabrasive wear resistance of the developed composite and a protective coating based on it indicate the feasibility of using a new material to improve the performance of vehicles (Table 2).

Table 1 - The composition of the ENCC coating

\begin{tabular}{|l|c|}
\hline \multicolumn{1}{|c|}{ Component } & pts.wt. \\
\hline Epoxy diane resin ED-20 & 100 \\
\hline hardener polyethylene polyamine (PEPA) & 10 \\
\hline 4-aminobenzoic acid modifier & 23.2 \\
\hline synthesized powdery titanium- & \\
aluminum mixture Ti $(70 \%)+\mathrm{Al}_{3} \mathrm{Ti}$ & $0.4-0.6$ \\
$(15 \%)+\mathrm{Ti}_{3} \mathrm{AlC}_{2}(15 \%)(d=15-18 \mathrm{~nm})$ & \\
\hline carbon discrete fibers FC-H & $0.04-$ \\
$(d=9-11 \mu \mathrm{m}, l=20-30 \mu \mathrm{m})$ & 0.06 \\
\hline powdery mixture $\mathrm{TiH}(65 \%), \mathrm{FeSiMn}$ & $55-65$ \\
$(30 \%), \mathrm{B}_{4} \mathrm{C}(5 \%)(d=63 \mu \mathrm{m})$ & \\
\hline
\end{tabular}

Table 2 - Properties of the developed ENCC protective coatings

\begin{tabular}{|l|c|}
\hline \multicolumn{1}{|c|}{ Properties } & Value \\
\hline Adhesion strength, $\sigma_{\mathrm{a}}, \mathrm{MPa}$ & 49.2 \\
\hline $\begin{array}{l}\text { Fracture stresses during } \\
\text { flexion, } \sigma_{f l}, \mathrm{MPa}\end{array}$ & 105.5 \\
\hline Impact strength, $W, \mathrm{~kJ} / \mathrm{m}^{2}$ & 23.2 \\
\hline Heat resistance, $T, \mathrm{~K}$ & 360 \\
\hline $\begin{array}{l}\text { Wear intensity under the } \\
\text { action of hydroabrasive, } I, \%\end{array}$ & 10 \\
\hline
\end{tabular}

Note. ENCC - developed material

\section{REFERENCES}

1. A.S. Mostovoy, Y.A. Kadykova, A.Z. Bekeshev, L.K. Tastanova, J. Appl. Polym. Sci. 135, 46651 (2018).

2. I.N. Burmistrov, A.S. Mostovoi, N.V Shatrova, L.G. Panova, D.V Kuznetsov, A.V Gorokhovskii, I.A. Il'inykh, Russ. J. Appl. Chem. 86, 765 (2013).

3. V. Kindrachuk, B. Fedelich, B. Rehmer, F. Peter, Metals (Basel). 9, 390 (2019).

4. V.M. Kindrachuk, J.F. Unger, Int. J. Fatigue 100, 215 (2017).

5. A. Panda, K. Dyadyura, P.P. Savchuk, V. Kashytskyi, V. Malets, J. Valíček, M. Harničárová, I. Pandová, L. Androvič, M. Kušnerová, MM Sci. J. (2019).

6. L.F. Sukhodub, K. Dyadyura, J. Nano- Electron. Phys. 10, 06003 (2018)

7. J.L. Bishop, M.D. Lane, M.D. Dyar, A.J. Brown, Clay Miner. 43, 35 (2008).

8. V. Efremenko, K. Shimizu, T. Pastukhova, Y. Chabak, M. Brykov, K. Kusumoto, A. Efremenko, Int. J. Mater. Res. 109, 147 (2018).

9. V. Marasanov, D. Stepanchikov, A. Sharko, O. Sharko, Int. Conf. DSMP 2020: Data Stream Mining \& Processing, 202 (2020).

10. V. Marasanov, D. Stepanchikov, A. Sharko, A. Sharko, 2020 IEEE 40th Int. Conf. Electron. Nanotechnol., 646 (IEEE: 2020).

11. K.A. Dyadyura, K.V. Berladir, P.V. Rudenko, O.A. Budnik, V.A. Sviderskij, Int. Conf. Nanomater. Appl. Prop. 02NSA04-1 (IEEE: 2016).

12. A. Panda, K. Dyadyura, M. Harničárová, J. Valíček, I. Pandová, Z. Palková, MM Sci. J. (2019).
Application of the developed protective coating in the restoration of vehicles allows to:

- reduce the wear intensity of parts by 2.4-3.6 times under the action of hydroabrasive;

- reduce the frequency of restoration of defective parts by 2.0-2.5 times.

\section{CONCLUSIONS}

A material was developed based on a modified 4aminobenzoic acid epoxy matrix filled with active dispersed particles in the form of a synthesized titaniumaluminum powder mixture $\left(\mathrm{Ti}(70 \%)+\mathrm{Al}_{3} \mathrm{Ti}(15 \%)+\right.$ $\left.\left.\mathrm{Ti}_{3} \mathrm{AlC}_{2}(15 \%)\right)(d=15-18 \mu \mathrm{m})\right)$ and powder mixture $\left(\mathrm{TiH}_{2}(65 \%)\right.$, FeSiMn (30 \%), $\left.\mathrm{B}_{4} \mathrm{C}(5 \%)\right)(d=63 \mu \mathrm{m})$, and CDFs FC-H $(d=9-11 \mu \mathrm{m}, l=20-30 \mu \mathrm{m})$ at the optimum content. The material is characterized by a lower wear intensity under the conditions of hydroabrasive compared to known world analogues.

This is evidence of the need to use the developed material to increase the hydroabrasive wear resistance of parts of water transport, which operate under the action of mechanical loads and elevated temperatures.

The application of the developed protective coating on the transport allows to reduce the wear intensity to the action of hydroabrasive parts by 2.4-3.6 times and the frequency of restoring defective parts by 2.0-2.5 times.

\section{ACKNOWLEDGEMENTS}

The publication contains the results of research conducted within the framework of the project 2020.02/393 "Development of nanopolymer composites for the restoration of the main mechanisms and bodies of water and land transport" funded by the National Research Fund of Ukraine from the state budget.

13. A. Buketov, M. Brailo, S. Yakushchenko, O. Sapronov, V. Vynar, O. Bezbakh, R. Negrutsa, Period. Polytech. Mech. Eng. 63, 171 (2019).

14. A. Buketov, O. Sapronov, M. Brailo, D. Stukhlyak, S. Yakushchenko, N. Buketova, A. Sapronova, V. Sotsenko, Adv. Mater. Sci. Eng. 2019, 1 (2019).

15. K.P. Antoev, S.N. Popov, N.V. Shadrinov, Mater. Sci. Forum. 945, 465 (2019)

16. A.V. Buketov, O.O. Sapronov, M.V. Brailo, P.O. Maruschak, S.V. Yakushchenko, S.V. Panin, V.D. Nigalatiy, Mech. Adv. Mater. Struct. 27, 1 (2020).

17. A.V. Buketov, M.V. Brailo, S.V. Yakushchenko, O.O. Sapronov, S.O. Smetankin, J. Mar. Eng. Technol. 19, 109 (2020).

18. A.V. Buketov, V.G. Kulinich, S.A. Smetankin, V.M. Yatsyuk, S.V. Yakushchenko, Compos. Mech. Comput. Appl. An Int. J. 11, 77 (2020).

19. A.V. Buketov, A.G. Kulinich, A.V Akimov, S.A. Smetankin, V.N. Gusev, R.N. Levkivskyi, Compos. Mech. Comput. Appl. An Int. J. 11, 99 (2020).

20. A. Buketov, A. Sapronova, O. Sapronov, N. Buketova, V. Sotsenko, M. Brailo, S. Yakushchenko, P. Maruschak, S. Panin, S. Smetankin, A. Kulinich, V. Kulinich, Compos. Mech. Comput. Appl. An Int. J. 11 No 2, 113 (2020).

21. A. Buketov, S. Yakushchenko, A. Menou, O. Bezbakh, R. Vrublevskyi， Y. Kalba， T. Cherniavska, D. Zhytnyk, O. Danylyuk, Commun. - Sci. Lett. Univ. Zilina. 23, B89 (2021). 


\section{Епоксидні нанокомпозити з підвищеною гідроабразивною зносостійкістю для використання у транспортних засобах}

А.В. Букетов, В.М. Гусев, А.Г. Кулініч, С.В. Якущенко, С.О. Сметанкін, В.В. Соценко, К.Ю. Юренін

Херсонська державна морська академія, просп. Ушакова, 20, 73003 Херсон, Украӥна

У роботі обтрунтовано, що важливою експлуатаційною властивістю засобів транспорту, яка визначає їх довговічність і ресурс роботи, є зносостійкість (що визначається інтенсивністю спрацювання) в умовах дії гідроабразиву. У цьому плані актуальним для відновлення деталей е використання полімерних, у тому числі і епоксидних, композитів та захисних покриттів на їх основі. Розроблено матеріал на основі модифікованої 4-амінобензойною кислотою епоксидної матриці, наповненої активними дисперсними частками у вигляді синтезованої порошкової титано-алюмініевої суміші ( $\mathrm{Ti}(70 \%)+\mathrm{Al}_{3} \mathrm{Ti}(15 \%)+$ $\left.\mathrm{Ti}_{3} \mathrm{AlC}_{2}(15 \%)\right)\left(d=15-18\right.$ нм) і порошкової суміші $\left(\mathrm{TiH}_{2}(65 \%), \mathrm{FeSiMn}(30 \%), \mathrm{B}_{4} \mathrm{C}(5 \%)\right)(d=63$ мкм), а також дискретних вуглецевих волокон FC-Н ( $d=9$-11 мкм, $l=20-30$ мкм) за оптимального вмісту, який мае кращі показники інтенсивності зношування в умовах дії гідроабразиву порівняно з відомими світовими аналогами. Це е свідченням необхідності використання розробленого матеріалу для підвищення гідроабразивної зносостійкості деталей водного транспорту, які експлуатуються в умовах впливу механічних навантажень та підвищених температур. Впровадження розробленого захисного покриття на транспорті дозволяе зменшити інтенсивність спрацювання до дії гідроабразиву деталей у 2,4-3,6 рази, а періодичність відновлення дефектних ділянок деталей у 2,0-2,5 рази.

Ключові слова: Нанокомпозитний матеріал, Інтенсивність зносу, Гідроабразив, Транспорт. 